\title{
Effect of Different Seed Scarification Treatments on Seed Germination Parameters of Ber (Ziziphus rotundifolia Lamk.) under Laboratory Conditions
}

\author{
Vikas Sheoran ${ }^{1}$, Mukesh Kumar²*, B.S. Yadav²*, Gulshan Yadav and J.R. Sharma ${ }^{1}$ \\ ${ }^{1}$ CCS Haryana Agricultural University, Hisar- 125004 (Haryana), India \\ $2 *$ CCS Haryana Agricultural University, Regional Research Station, Bawal (Rewari)-123501 \\ Haryana, India \\ *Corresponding author
}

\section{A B S T R A C T}

\begin{tabular}{|c|c|}
\hline & \multirow{4}{*}{ 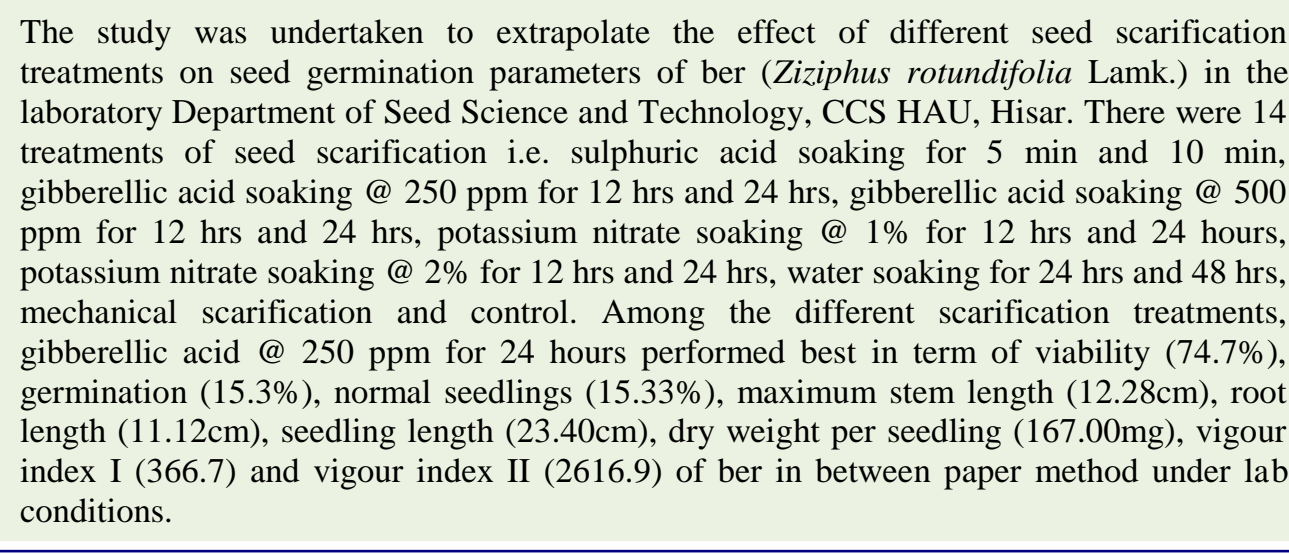 } \\
\hline & \\
\hline & \\
\hline & \\
\hline
\end{tabular}

\section{Introduction}

Ziziphus rotundifolia Lamk. is a wild species of ber used as one of the important rootstocks for commercially grown ber orchard in India due to tap root system and vigorous growth. It belongs to family Rhamnaceae. Earlier, the fruits of this species were used for consumption, later on, it becomes neglected due to the evolution of high yielding varieties. It is known to be indigenous to the area stretching from India to south-western China and Malaya (Vavilov, 1951). In India, the area under ber cultivation in the second advance estimate is 49000 hectares with a production of 481000 MT 2016-17 (Anonymous, 2017).

Its fruits are used as liver tonic having a protective effect for increasing stamina, weight gain and also serve as antioxidant and anti-cancer agent. Its pulp contains moisture, protein, fat, carbohydrate, iron, carotene, calcium, phosphorus, thiamine, riboflavin, vitamin C etc. (Tripathi and Tripathi, 2014). 
Ber plants raised from seeds are not uniform and precautious in comparison to vegetatively propagated plants. The stony nature of shell (endocarp) cause poor and delayed germination of seeds. Seed coat has an inhibitory role in gaseous exchange and seed germination. Dormancy of the hard seed can be broken by gibberellic acid treatment, scarification, stratification, chilling treatment, hot water treatment, soaking in water and acid treatment depending on the kind of dormancy (Kher and Nataraj, 2015). Early emergence or germination can be achieved by soaking the seeds in water; followed by surface drying before sowing; speedy germination and vigorous seedlings result into higher crop yield. A critical soaking period is needed for each crop/variety must be within the safe limit (Harris et al., 2000). Sulphuric acid increases the germination of seed by softening the seed coat and allow permeability to air and water (Brijwal et al., 2013). Gibberellins are implicated in the control and promotion of germination. A biochemical reaction known to be enhanced by gibberellic acid is the synthesis of hydrolases (especially, $\alpha$ amylase) in the endosperm of cereal grains. Its breakdown is generally believed to be an essential process for germination (Kolumbina et al., 2006). Further, Lahuti and his associates (2003) also revealed that $\mathrm{GA}_{3}$ hormone stimulates the cell wall to release and transmit its calcium into the cytoplasm. $\mathrm{GA}_{3}$ affects the enzyme synthesis that produces mRNA and thereby increases DNA replication and induces analysis of endospermic materials in the seed.

\section{Materials and Methods}

The present investigation was carried out in the laboratory Department of Seed Science and Technology, CCS HAU, Hisar. Ripe fruits of $\mathrm{Z}$. rotundifolia were harvested in the month of March from experimental orchard, Department of Horticulture, CCS HAU, Hisar.
Fruits were kept in water for 2-3 days to remove peel and adhered pulp portion from the stone. The extracted seeds/stones were cleaned thoroughly, dried in shade and stored at room temperature. Seeds were treated with different scarification treatments viz., $\mathrm{T}_{1}$ : control, $\mathrm{T}_{2}$ : sulphuric acid soaking for $5 \mathrm{~min}$, $\mathrm{T}_{3}$ : sulphuric acid soaking for $10 \mathrm{~min}, \mathrm{~T}_{4}$ : gibberellic acid soaking@ 250 ppm for 12 hrs, $\mathrm{T}_{5}$ : gibberellic acid soaking @ 500 ppm for $12 \mathrm{hrs}, \mathrm{T}_{6}$ : gibberellic acid soaking @ 250 ppm for $24 \mathrm{hrs} \mathrm{T}_{7}$ : gibberellic acid soaking @ $500 \mathrm{ppm}$ for $24 \mathrm{hrs}, \mathrm{T}_{8}$ : potassium nitrate soaking@1.0\% for 12 hrs, T9: potassium nitrate soaking @ 2.0\% for $12 \mathrm{hrs,} \mathrm{T}_{10}$ : potassium nitrate soaking @ 1.0\% for $24 \mathrm{hrs,}$ $\mathrm{T}_{11}$ : potassium nitrate soaking @ 2.0\% for 24 hrs, $\mathrm{T}_{12}$ : water soaking for $24 \mathrm{hrs} \mathrm{T}_{13}$ : water soaking for $48 \mathrm{hrs} \mathrm{T}_{14}$ : mechanical scarification. These treatments were applied to the ber seeds/stones in mentioned concentration during May.

Fifty seeds per replication were soaked in 50 $\mathrm{ml}$ water for 16 hours at $25^{\circ} \mathrm{C}$ to activate dehydrogenase enzymes. Thereafter, seeds were sectioned longitudinally with a sharp blade and stained in $0.01 \%$ tetrazolium solution $(2,3,5-\quad$ triphenyl tetrazolium chloride) for 5 hours at room temperature in petri plates (Fig. 1). Then the solution was drained and seeds were washed in running tap water and examined under a magnifying glass. Completely red stained seeds were considered as normal viable seeds and expressed in percentage.

For calculating germination (\%) the treated ber seeds were sown in between paper method and on the paper method for laboratory studies. In between paper method the seeds were placed in between the papers (Fig. 2), while, on the paper method the seeds were kept on the paper, both were moistened with distilled water and kept at $25 \pm 2{ }^{0} \mathrm{C}$ temperature with $80-85$ percent relative 
humidity in seed incubator. The final count was taken after 30 days of sowing and only normal seedlings were counted for percent germination as per the rules of International Seed Testing Association (ISTA, 2010).

Germination $\%=\frac{\text { Number of seeds germinated }}{\text { Total number of seads sown }} \times 100$

The mean germination time (MGT) was calculated by counting the germinated seeds used for the standard germination test. The germination counts were taken at 24 hours interval and MGT was calculated by using the following formula:

MGT $=\frac{\sum n d}{\sum n}$

Where, $n=$ number of seeds which germinate on day $d$, and $d=$ number of days counted from the beginning of germination test. Seedling length $(\mathrm{cm})$ of ten randomly selected normal seedlings per treatment was recorded with meter rod from root tip to the shoot tip. The average length per treatment was expressed in centimeter. Dry weight per seedling (mg) was calculated by taking five seedlings per treatment used for dry weight and kept in hot air oven drier at $60 \pm 2^{\circ} \mathrm{C}$ temperature till the constant weight achieved. Dried seedlings were weighed on the digital electric balance and average values were recorded in a milligram. Seedling vigour index I and II were calculated as per formula:

1. Vigour index-I = Standard germination (\%) $\times$ Average seedling length $(\mathrm{cm})$

2. Vigour index-II= Standard germination (\%) $\times$ Average seedling dry weight $(\mathrm{mg})$

Statistical analysis of data collected during the study was analysed by applying the technique of analysis of variance by Panse and Sukhatme (1985).

\section{Results and Discussion}

\section{Seed viability and germination}

The maximum seed viability $(74.7 \%)$ and germination (15.3\%) were recorded with gibberellic acid soaking @ 250 ppm for 24 hours, which was at par with gibberellic acid soaking@ @ 500 ppm for 12 and 24 hours, respectively. However, minimum seed viability $(61.3 \%)$ was recorded in seed scarification treatment of sulphuric acid soaking for 10 minutes. The lowest germination percentage was recorded in control $(6.7 \%)$. The minimal mean germination time (22.3 days) in mechanical scarification. However, it was maximum (28.7 days) in control; followed by water soaking for 48 hours (27.7 days). Soaking of ber seed with gibberellic acid at 250 ppm for 24 hours and $500 \mathrm{ppm}$ for 12 hours increase the seed germination significantly $(\mathrm{P}<0.05)$ over control (Fig. 3). Soaking of ber seed with gibberellic acid at $250 \mathrm{ppm}$ for 24 hours increased germination $(74.7 \%)$ by 128.4 percent over control (6.7\%). This may be due to the reason that gibberellic acid (GA) helps in the synthesis of hydrolytic enzymes like $\alpha$ amylase when applied exogenously. The aleurone layer of the seed synthesizes and secretes $\alpha$-amylase during germination (Kolumbina et al., 2006). $\alpha$-amylase participates in the breakdown of (endosperm) starch, protein and lipids, which helps in the initiation of germination. The scarification methods also improve the absorption of water by the seed coat (Karimpour et al., 2013). Hence, GA increases the rate of reactions responsible for seed germination.

\section{Seedling evaluation}

Normal seedling percent was found the maximum (15.33\%) with gibberellic acid soaking@250 ppm for 24 hours; followed by gibberellic acid soaking @ 500 ppm for 24 
hours and gibberellic acid soaking @ 500 ppm 12 hours as compared to other scarification treatments. However, minimum normal seedlings (6.67\%) were found in control/ untreated seeds (Table and 2).

Minimum abnormal seedlings $(9.33 \%)$ were recorded in mechanical scarification, however, maximum abnormal seedlings were recorded in control (16.67 \%). Damaged seeds $(6.67 \%)$ were recorded lowest in control, however, these were highest $(22.00 \%)$ in mechanical scarification. Lowest hard seeds (51.00\%) were recorded with gibberellic acid soaking @ 500 for 24 hours, which was at par with gibberellic acid soaking @ 250 for 24 hours as compared to other seed scarification treatments. However, highest hard seeds (70\%) were observed in control/ untreated seeds. Gibberellic acid soaking @ 250 ppm for 24 hours increased the normal seedling by 129.84 percent but failed to reduce the abnormal seedlings which were higher in mechanical scarification. However, damaged seeds were lesser in control/ untreated due to less chance for the entrance of harmful bioagents. Hard seed percent was reduced by 24.76 percent with gibberellic acid soaking@ $250 \mathrm{ppm}$ for 24 hours over control (Table 2). This might be due to an increase in osmotic uptake of nutrients (Nimbalkar, 2012).

Stem length, root length, seedling length and dry weight per seedling

The results in Table 3 revealed that stem length, root length, seedling length and dry weight per seedling were increased by all the scarification treatments in comparison to control. Maximum stem length $(12.28 \mathrm{~cm})$ was observed in gibberellic acid soaking @ 250 ppm for 24 hours; followed by gibberellic acid soaking @ 500 ppm for 24 hours, however, minimum stem length $(6.94 \mathrm{~cm})$ was observed in control, which was at par with water soaking for 24 hours and water soaking for 48 hours (Table 3).
Maximum root length $(11.12 \mathrm{~cm})$ was observed in gibberellic acid soaking @ 250 ppm for 24 hours; followed by gibberellic acid soaking@ 500 ppm for 24 hours and 12 hours, however, minimum root length (6.26 $\mathrm{cm}$ ) was observed control, which was at par with water soaking for 48 hours and 24 hours. The seedling length was observed maximum $(23.40 \mathrm{~cm})$ in gibberellic acid soaking@250 ppm for 24 hours, which was at par with the gibberellic acid soaking @ 500 ppm for 24 hours. Minimum seedling length $(13.20 \mathrm{~cm})$ was observed in control; followed by water soaking treatment for 24 hours.

Dry weight per seedling was recorded as highest $(167.00 \mathrm{mg})$ in the treatment of gibberellic acid soaking @ 250 ppm for 24 hours, which was at par with the gibberellic acid soaking @ 500 ppm for 24 hours and 12 hours, however, lowest dry weight per seedling (150.3 mg) was recorded in control, which was at par with the water soaking for 24 and 48 hours and mechanical scarification. The exogenous soaking of ber seed with gibberellic acid @ 250 ppm for 24 hours resulted into increase in osmotic uptake of nutrients, causing cell elongation and hence increased the stem length, root length, and seedling length. The results are in confirmation with the results achieved by Patel et al., (2016) in custard apple. Dry weight per seedling was increased due to the overall growth of seedlings and increased rate of photosynthesis and translocation of photosynthates within seedlings and thus resulted into higher dry weight per seedling. Similar trends were also observed by Chaudhary and Chakrawar (1981) (kagzi lime); Sasikala and Srimathi (2006) (papaya).

\section{Vigour index}

The results on vigour index I and II are presented in Table 4. 
Table.1 Effect of seed scarification treatments on seedling evaluation of Ziziphus rotundifolia in between paper method

\begin{tabular}{|l|c|c|c|c|}
\hline Treatments & $\begin{array}{c}\text { Normal } \\
\text { seedlings } \\
(\%)\end{array}$ & $\begin{array}{c}\text { Abnormal } \\
\text { seedlings } \\
(\%)\end{array}$ & $\begin{array}{c}\text { Damaged } \\
\text { seeds (\%) }\end{array}$ & $\begin{array}{c}\text { Hard } \\
\text { seeds } \\
(\%)\end{array}$ \\
\hline Control & 6.67 & 16.67 & 6.67 & 70.00 \\
\hline Sulphuric acid soaking for 5 min & 12.67 & 13.67 & 18.00 & 54.67 \\
\hline Sulphuric acid soaking for 10 min & 11.33 & 15.67 & 18.00 & 54.00 \\
\hline Gibberellic acid soaking @ 250 ppm for 12 hrs & 13.33 & 14.00 & 17.33 & 55.33 \\
\hline Gibberellic acid soaking @ 500 ppm for 12 hrs & 14.67 & 14.00 & 18.33 & 53.00 \\
\hline Gibberellic acid soaking @ 250 ppm for 24 hrs & 15.33 & 16.33 & 15.67 & 52.67 \\
\hline Gibberellic acid soaking @ 500 ppm for 24 hrs & 15.00 & 15.67 & 18.33 & 51.00 \\
\hline Potassium nitrate soaking @ 1.0\% for 12 hrs & 9.33 & 12.00 & 17.00 & 61.67 \\
\hline Potassium nitrate soaking @ 2.0\% for 12 hrs & 10.67 & 12.00 & 16.00 & 61.33 \\
\hline Potassium nitrate soaking @ 1.0\% for 24 hrs & 12.00 & 13.33 & 16.67 & 58.00 \\
\hline Potassium nitrate soaking @ 2.0\% for 24 hrs & 13.33 & 12.67 & 16.67 & 57.33 \\
\hline Water soaking for 24 hrs & 8.67 & 14.67 & 12.00 & 64.67 \\
\hline Water soaking for 48 hrs & 9.33 & 12.67 & 15.33 & 63.00 \\
\hline Mechanical scarification & 13.33 & 9.33 & 22.00 & 55.33 \\
\hline C.D. at 5\% & 1.79 & 0.69 & 0.98 & 1.90 \\
\hline
\end{tabular}

Table.2 Effect of seed scarification treatments on stem length, root length, seedling length and dry weight per seedling of Ziziphus rotundifolia in between paper method

\begin{tabular}{|l|c|c|c|c|}
\hline Treatments & $\begin{array}{c}\text { Stem } \\
\text { length } \\
\text { (cm) }\end{array}$ & $\begin{array}{c}\text { Root } \\
\text { length } \\
\text { (cm) }\end{array}$ & $\begin{array}{c}\text { Seedling } \\
\text { length } \\
\text { (cm) }\end{array}$ & $\begin{array}{c}\text { Dry wt. } \\
\text { /seedling } \\
\text { (mg) }\end{array}$ \\
\hline Control & 6.94 & 6.26 & 13.20 & 150.30 \\
\hline Sulphuric acid soaking for 5 min & 8.65 & 7.88 & 16.19 & 165.00 \\
\hline Sulphuric acid soaking for 10 min & 9.43 & 8.56 & 17.99 & 160.00 \\
\hline Gibberellic acid soaking @ 250 ppm for 12 hrs & 10.72 & 9.66 & 20.38 & 161.00 \\
\hline Gibberellic acid soaking @ 500 ppm for 12 hrs & 11.15 & 10.01 & 21.17 & 162.70 \\
\hline Gibberellic acid soaking @ 250 ppm for 24 hrs & 12.28 & 11.12 & 23.40 & 167.00 \\
\hline Gibberellic acid soaking @ 500 ppm for 24 hrs & 11.70 & 10.64 & 22.34 & 164.00 \\
\hline Potassium nitrate soaking @ 1.0\% for 12 hrs & 8.52 & 7.68 & 16.20 & 155.00 \\
\hline Potassium nitrate soaking @ 2.0\% for 12 hrs & 8.89 & 8.11 & 17.00 & 156.70 \\
\hline Potassium nitrate soaking @ 1.0\% for 24 hrs & 8.96 & 8.14 & 17.09 & 158.00 \\
\hline Potassium nitrate soaking @ 2.0\% for 24 hrs & 9.60 & 8.65 & 18.24 & 160.00 \\
\hline Water soaking for 24 hrs & 7.51 & 6.74 & 14.24 & 151.00 \\
\hline Water soaking for 48 hrs & 7.97 & 7.24 & 15.20 & 154.00 \\
\hline Mechanical scarification & 8.56 & 7.75 & 16.32 & 155.00 \\
\hline C.D. at 5\% & 1.10 & 1.31 & 1.73 & 5.40 \\
\hline
\end{tabular}


Table.3 Effect seed scarification treatments on vigour index of Ziziphus rotundifolia in between paper method

\begin{tabular}{|l|c|c|}
\hline \multirow{2}{*}{ Treatments } & \multicolumn{2}{|c|}{ Vigour index } \\
\hline Control & 1 & II \\
\hline Sulphuric acid soaking for 5 min & 28.0 & 1002.5 \\
\hline Sulphuric acid soaking for 10 min & 203.8 & 2090.5 \\
\hline Gibberellic acid soaking @ 250 ppm for 12 hrs & 271.7 & 1812.8 \\
\hline Gibberellic acid soaking @ 500 ppm for 12 hrs & 310.6 & 2146.1 \\
\hline Gibberellic acid soaking @ 250 ppm for 24 hrs & 366.7 & 2386.8 \\
\hline Gibberellic acid soaking @ 500 ppm for 24 hrs & 342.5 & 2516.9 \\
\hline Potassium nitrate soaking @ 1.0\% for 12 hrs & 205.2 & 1963.8 \\
\hline Potassium nitrate soaking @ 2.0\% for 12 hrs & 226.6 & 2088.8 \\
\hline Potassium nitrate soaking @ 1.0\% for 24 hrs & 227.8 & 2106.1 \\
\hline Potassium nitrate soaking @ 2.0\% for 24 hrs & 249.3 & 2187.2 \\
\hline Water soaking for 24 hrs & 123.5 & 1309.2 \\
\hline Water soaking for 48 hrs & 141.8 & 1436.8 \\
\hline Mechanical scarification & 217.5 & 2066.1 \\
\hline C.D. at 5\% & 39.9 & 317.7 \\
\hline
\end{tabular}

Fig.1 Viability of seeds in tetrazolium test

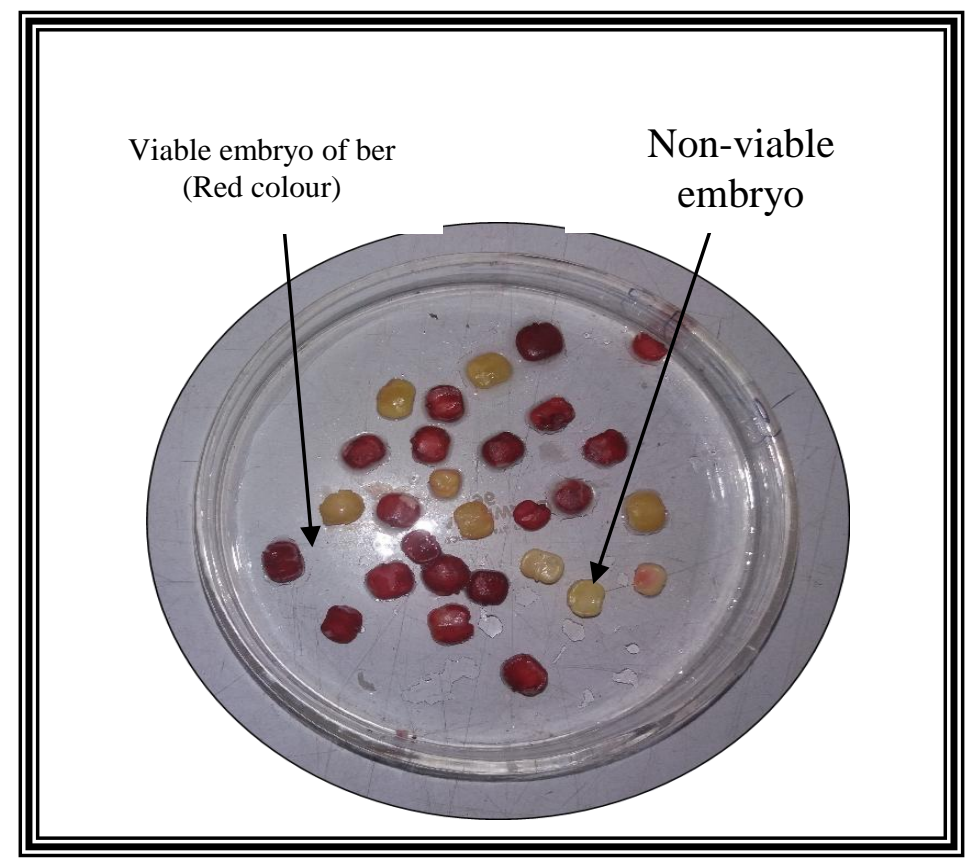


Fig.2 Seed sowing in between paper method
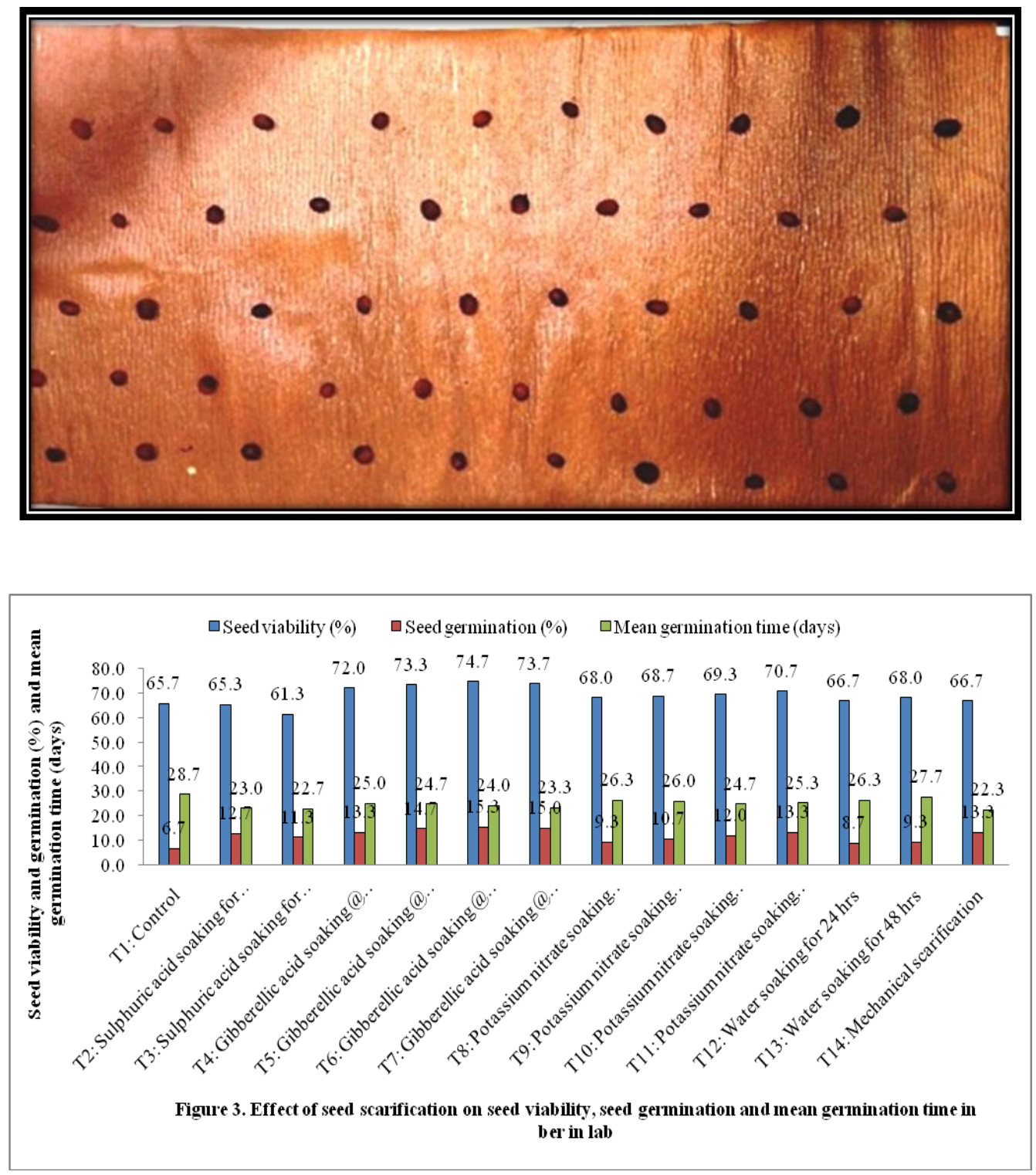

The vigour index I and II were increased significantly over control with different scarification treatments except water soaking for 24 hours. The maximum vigour index I (366.67) was recorded in gibberellic acid soaking@ 250 ppm for 24 hours, which was at par with gibberellic acid soaking @ 500 ppm for 24 hours, however, lowest vigour index I (88.0) was observed in control, which was closely followed by water soaking for 24 hours (Table 4).
Vigour index II was recorded as maximum (2616.9) in gibberellic acid soaking @ 250 ppm for 24 hour, which was at par with the gibberellic acid soaking @ 500 ppm for 24 hours and in gibberellic acid soaking @ 500 ppm for 12 hours. However, minimum vigour index II (1002.5) was observed in control; followed by water soaking for 24 hours.

In the present study, seed scarification treatment with gibberellic acid soaking @ 250 ppm for 24 hours resulted in highest vigour 
index I and II by 316.70 and 161.04 percent, respectively, over control. Vigour index II is based on the rate of dry matter accumulation and depicts both the reserve food material availability as well as an indicator of no more seed dormancy. Higher the vigour index II is directly correlated with seed vigour. Vigour index I is based on the seedling length. In the present study, gibberellic acid increased the seedling length, which in turn, increased the vigour index I. Both the indices provide a view that the ber seed treated with gibberellic acid @ 250 ppm for 24 hours recorded higher plant length as well as higher dry matter accumulation.

On the basis of this study it can be concluded that the seeds treated with gibberellic acid @ $250 \mathrm{ppm}$ for 24 hours performed best in relation to viability, germination, normal seedlings, stem length, root length as well as seedling length, dry weight per seedling, vigour index I and II of ber in between paper method under lab conditions.

\section{References}

Anonymous. 2017. Area and Production of Horticulture Crops - All India Press Information Bureau, Government of India, Ministry of Agriculture. 20 May, 2017.

Brijwal, M, Kumar, R and Mishra, D S. 2013. Effect of pre-sowing treatments on seed germination of guava (Psidium guajava L.) under Trai region of Uttrakhand. Progressive Horticulture, 45(1): 154-159.

Chaudhary, B K and Chakrawar, V R. 1981. Effect of seed treatment with certain growth regulators on the shoot and root development of Kagzi lime (Citrus aurantifolia Swingle). Journal of Maharashtra Agricultural Universities, 6(1): 19-21.

Harris, D, Tripathi, R S and Joshi, A 2000.
On-farm seed priming to improve crop establishment and yield in dry direct seeded rice. Paper presented at the workshop on dry seeded rice Technology, Bangkok, Thailand.

ISTA. 2010. International Rules for Seed Testing: edition 2010. ISTA, Bassersdorf, Switzerland.

Karimpour S, Davarynejad G H, Roohbakhsh H and Ardakani E. 2013. Data on scarification and stratification treatments on germination and seedling growth of Ziziphus Jujuba seeds. Advances in Environmental Biology, 7(3): 501-505.

Kher, M M and Nataraj, M. 2015. Effect of sulphuric acid treatment on breaking of seed dormancy and germination of Indian Doum Palm, Hyphaene dichotoma, a threatened and endemic palm. Environmental and Experimental Biology, 13: 99-101.

Kolumbina, M, Blesingh, $\mathrm{M}$ and Mares, D J. 2006. $\alpha$-amylase and programmed cell death in aleurone of ripening wheat grains. Journal of Experimental Botany, 54(4): 877-885.

Lahuti, M, Zare-hasanabadi, $\mathrm{M}$ and Ahmadian, R. 2003. Biochemistry and physiology of vegetable hormones. Ferdosi University Mashhad.

Nimbalkar, S D, Jadhav, Y S, Adat, S S and Savvashe, A Y. 2012. Effect of different seed treatments on germination and growth of karonda (Carissa congesta W.). Green Farming, 3(3): 340-42.

Panse, V G and Sukhatme, P V. 1985. Statistical Methods for Agricultural Workers. Indian Council of Agricultural Research Publication, 8789.

Patel, D D, Gaikwad, S S and Patel, K. 2016. Effect of seed priming treatments on germination and seedling vigour of custard apple (Annona squamosa). 
Current Horticulture, 4(2): 21-24.

Sasikala, S and Srimathi, P. 2006. Influence of storage period and $\mathrm{GA}_{3}$ on germination and vigour of papaya seed. Progressive Horticulture, 38(2): 195-98.

Tripathi, P and Tripathi, S. 2014. Ziziphus jujuba: A phytopharmacological
Review. International Journal of Research and Development in Pharmacy \& Life Science, 3: 959-966. Vavilov, N I. 1951. The origin, variation, immunity and breeding of cultivated crops. Chronic Botanica, Waltham mass, U.S.A. (Translation from Russian selected writings).

\section{How to cite this article:}

Vikas Sheoran, Mukesh Kumar, B.S. Yadav, Gulshan Yadav and Sharma, J.R. 2018. Effect of Different Seed Scarification Treatments on Seed Germination Parameters of Ber (Ziziphus rotundifolia Lamk.) under Laboratory Conditions. Int.J.Curr.Microbiol.App.Sci. 7(12): 19721980. doi: https://doi.org/10.20546/ijcmas.2018.712.227 